\title{
FAKTOR-FAKTOR YANG MEMPENGARUHI MASYARAKAT MENYALURKAN DONASI MELALUI PLATFORM CROWDFUNDING BERBASIS ONLINE
}

\section{FACTORS AFFECTING SOCIETY CHANNELING DONATIONS THROUGH ONLINE- BASED CROWDFUNDING PLATFORMS}

\section{I.A. Aziz'1a; Nurwahidin'² I.Chailis ${ }^{3}$}

1aProgram Studi Kajian Wilayah Timur Tengah dan Islam, Sekolah Kajian Stratejik dan Global, Universitas Indonesia, Jl. Salemba Raya 4, Jakarta, 10430, Indonesia, e-mail: imamabdulaziz08@gmail.com

${ }^{2}$ Program Studi Kajian Wilayah Timur Tengah dan Islam, Sekolah Kajian Stratejik dan Global, Universitas Indonesia, Jl. Salemba Raya 4, Jakarta, 10430, Indonesia

3Program Studi Kajian Wilayah Timur Tengah dan Islam, Sekolah Kajian Stratejik dan Global, Universitas Indonesia, Jl. Salemba Raya 4, Jakarta, 10430, Indonesia

\begin{abstract}
ABSTRAK
Penggalangan donasi berbasis online dengan sistem crowdfunding lebih mampu menarik perhatian masyarakat karena cangkupannya yang luas dan dinilai lebih mudah digunakan untuk menggalang dana. Penelitian ini bertujuan untuk mengetahui faktorfaktor yang mempengaruhi masyarakat dalam menyalurkan donasi secara online. Metode penelitian yang digunakan untuk menguji faktor-faktor tersebut berupa deskriptif kuantitatif dengan Structural Equation Modelling (SEM). Berdasarkan analisa data yang dilakukan, diperoleh hasil penelitian bahwa faktor religiusitas, efektifitas kampanye dan inovasi platform berpengaruh positif sedangkan faktor jiwa sosial masyarakat berpengaruh negatif. Secara keseluruhan, semua faktor cukup signifikan dalam mempengaruhi masyarakat untuk berdonasi melalui crowdfunding berbasis online. Temuan penelitian ini mengungkapkan bahwa faktor jiwa sosial masyarakat berpengaruh negatif karena masyarakat berpendapat bahwa jika seseorang memiliki jiwa sosial tinggi, maka lebih cenderung memilih untuk menyalurkan bantuan atau berdonasi secara langsung dan tanpa menggunakan sistem online.
\end{abstract}

Kata Kunci: Crowdfunding; Donasi Online; kitabisa.com

\begin{abstract}
Raising online-based donations with crowdfunding systems is better able to attract attention of society because of its large scope and is considered easier to use to raise funds. This study aims to determine factors affecting society in channeling online donations. The research method used to test these factors is quantitative descriptive with Structural Equation Modeling (SEM). Based on the data analysis conducted, the results of study showed that factors of religiosity, campaign effectiveness and platform
\end{abstract}


innovation had a positive effect while the social soul factors of society had a negative effect. Overall, all factors are quite significant in influencing society to donate through crowdfunding based online. The findings of this study reveal that social soul factors of society have a negative effect because the public believes that if a person has a high social life then it is more likely to choose to channel aid or donate directly and without using an online system.

Keywords: Crowdfunding; Online Donation; kitabisa.com

Aziz, Imam Abdul. 2019. Faktor-Faktor yang Mempengaruhi Masyarakat Menyalurkan Donasi Melalui Platform Crowdfunding Berbasis Online. Jurnal Syarikah 5 (1): 94109

\section{PENDAHULUAN}

Inovasi teknologi internet yang sedang mengalami kemajuan juga dapat dimanfaatkan untuk menggalang donasi sosial, kemanusiaan, dan penanganan korban bencana alam. Terdapat banyak perusahaan rintisan berbasis internet (startup) yang memanfaatkan sistem crowdfunding untuk menggalang dana donasi dari masyarakat. Model crowdfunding donation-based yang digunakan untuk penggalangan dana, terbukti sukses mengumpulkan dana bantuan khususnya pada saat terjadi bencana alam dan keadaan darurat lainnya.

Proses crowdfunding terjadi dimana sekelompok orang (berjumlah banyak) secara finansial memberikan uang yang jumlahnya relatif kecil sebagai sumbangan atau ikut mendukung untuk mendanai proyek yang dapat berpotensi mendapatkan imbalan (Wicks, 2013:5). Hemer (2011) mengungkapkan, usaha crowdfunding umumnya dilakukan melalui internet.
Aprilia dan Wibowo (2017) menjelaskan bahwa di Indonesia, praktik crowdfunding bukanlah hal baru, meskipun nama itu sendiri belum banyak dikenal oleh masyarakat. Penggalangan dana yang pernah dilakukan dalam bentuk mengumpulkan koin juga merupakan bentuk donasi crowdfunding. Meskipun masyarakat di Indonesia belum banyak mengenal istilah crowdfunding, sudah ada beberapa situs web yang memfasilitasi crowdfunding di Indonesia seperti patungan.net, wujudkan.com, gagas.web.id, dan kitabisa.com.

Menurut laporan keuangan yang diterbitkan oleh kitabisa.com, platform penggalangan donasi tersebut terus mengalami peningkatan pendapatan setiap tahun. Hingga puncaknya dialami pada tahun 2017 yang dilaporkan pada laporan keuangan sebagai berikut: 
Tabel 1.

Laporan Perolehan Program Penggalangan Dana Yayasan Kitabisa

\begin{tabular}{|l|l|l|}
\hline No & \multicolumn{1}{|c|}{ Tanggal } & $\begin{array}{c}\text { Total Pengumpulan Dana } \\
\text { Kitabisa.com }\end{array}$ \\
\hline 1 & $\begin{array}{l}31 \quad \text { Maret } \\
2016\end{array}$ & Rp. 3.731.544.517 \\
\hline 2 & $\begin{array}{l}31 \\
\text { Desember } \\
2016\end{array}$ & Rp. 43.536.588.991 \\
\hline 3 & $\begin{array}{l}31 \quad \text { Maret } \\
2017\end{array}$ & Rp. 17.864.056.400 \\
\hline 4 & $\begin{array}{l}31 \\
\text { Desember } \\
2017\end{array}$ & Rp. 103.020.835.798 \\
\hline
\end{tabular}

Sumber: Laporan Keuangan Yayasan Kitabisa 2016-2017

Selain itu terdapat platform "Aksi Cepat Tanggap" (ACT) juga merupakan salah satu platform crowdfunding besar di Indonesia. Menurut laporan yang dikeluarkan ACT, yayasan yang terlebih dahulu memiliki izin resmi dengan payung hukum yayasan yang bergerak di bidang sosial dan kemanusiaan per tanggal 21 April 2005 tersebut mengalami peningkatan dalam penggalangan dana kemanusiaan selama delapan tahun terakhir yang dapat dilaporkan sebagai berikut:

Tabel 2

Laporan Perolehan Dana Kemanusiaan Aksi Cepat Tanggap

\begin{tabular}{|l|l|l|}
\hline No & \multicolumn{1}{|c|}{ Tanggal } & $\begin{array}{c}\text { Total Pengumpulan } \\
\text { Dana Kemanusiaan } \\
\text { ACT }\end{array}$ \\
\hline 1 & $\begin{array}{l}31 \text { Desember } \\
2010\end{array}$ & Rp. 25.114.880.931 \\
\hline 2 & $\begin{array}{l}31 \text { Desember } \\
2011\end{array}$ & Rp. 13.806.411.565 \\
\hline 3 & $\begin{array}{l}31 \quad \text { Desember } \\
2012\end{array}$ & Rp. 32.119.729.006 \\
\hline 4 & $\begin{array}{l}31 \quad \text { Desember } \\
2013\end{array}$ & Rp. 41.943.979.738 \\
\hline 5 & $\begin{array}{l}31 \text { Desember } \\
2014\end{array}$ & Rp. 87.666.115.382 \\
\hline 6 & $\begin{array}{l}31 \quad \text { Desember } \\
2015\end{array}$ & Rp. 87.380.075.050 \\
\hline
\end{tabular}

\begin{tabular}{|l|l|l|}
\hline 7 & $\begin{array}{l}31 \quad \text { Desember } \\
2016\end{array}$ & Rp. 141.338.073.460 \\
\hline 8 & $\begin{array}{l}31 \quad \text { Desember } \\
\text { 2017 }\end{array}$ & Rp. 262.015.679.850 \\
\hline \multicolumn{2}{|l|}{$\begin{array}{l}\text { Sumber: Laporan Keuangan Aksi Cepat Tanggap 2011- } \\
2017\end{array}$}
\end{tabular}

Data tabel 2 menggambarkan bahwa kemajuan teknologi dapat sangat membantu kehidupan masyarakat. Menurut penelitian Sitanggang (2017), masyarakat yang berdonasi pada platform kitabisa.com umumnya lebih tertarik kepada objek donasi yang bertema kesehatan dan agama. Sitanggang (2017) juga menjelaskan para donatur melakukan donasi online didasari dengan tingginya rasa empati alturalisme dan tanggungjawab sosial. Hal ini menjadi menarik untuk diteliti dengan metode kuantitatif untuk mengetahui benarkah masyarakat yang memiliki tingkat religiusitas dan jiwa sosial tinggi akan dapat mempengaruhi keputusannya dalam berdonasi secara online. Selain itu, terdapat beberapa faktor yang diikut sertakan pada penelitian ini yang diadopsi dari penelitian-penelitian terdahulu untuk menguji kembali teoriteori terdahulu dengan keadaan saat ini.

\section{MATERI DAN METODE}

Terdapat banyak faktor yang menyebabkan masyarakat ikut serta membantu meringankan beban sesama dengan cara berkontribusi menyalurkan donasi melalui platform crowdfunding. Menurut penelitian kualitatif yang dilakukan Sitanggang (2017), masyarakat yang menyalurkan donasi melalui platform kitabisa.com lebih banyak meminati capaign donasi yang bertemakan kesehatan dan agama, sedangkan masyarakat ikut serta 
menyalurkan donasi online karena memiliki nilai empati, nilai gotong royong dan nilai tanggungjawab sosial. Selain itu, penelitian yang dilakukan oleh Tirdanatan dkk. (2014) menjelaskan tentang faktor-faktor yang memiliki pengaruh dalam evaluasi kebutuhan donatur crowdfunding donation based diantaranya yaitu faktor inovasi dan efektifitas kampanye. Dari kedua tinjauan kedua penelitian diatas maka perlu dilakukan penelitian secara kuantitatif untuk mengetahui kebenaran teori.

\section{Pengertian Fintech}

Teknologi Finansial atau yang sering dikenal sebagai financial technology (fintech) menurut Bank Indonesia adalah sistem keuangan yang melibatkan teknologi di dalamnya untuk menghasilkan suatu layanan jasa keuangan, produk atau model bisnis baru yang dapat memberikan kelancaran, kemudahan, keamanan serta efisiensi pembayaran yang akan berdampak pada stablitas moneter dan stabilitas keuangan. Otoritas Jasa Keuangan (OJK) mengatur fintech sebagaimana UndangUndang Inovasi Keuangan Digital (IKD), yaitu pembaruan dari model bisnis yang melibatkan ekosistem digital dan memberikan jasa atau nilai tambah baru di sektor keuangan.

Dari konsep ini, kemudian mulai banyak bermunculan startup yang bergerak di bidang fintech. Di Indonesia sendiri pada tahun 2018, startup fintech sudah mulai menguasai bidang ekonomi. Startup-startup fintech di Indonesia tersebut diantaranya kitabisa.com, act.com, cekaja.com, gopay, paytren, dana, uangteman.com,

pinjam.com, cekpremi.com, bareksa.com, kejora.com, doku.com, veritrans.com, kartuku.com, dan masih banyak lagi. Distribusi fintech pada tahun 2018 didominasi oleh jenis fintech payment gateway. Hal ini berjalan seiring dengan kemajuan e-commerce atau situs jual beli online yang menggunakan sistem pembayaran secara transfer.

Otoritas Jasa Keuangan sebagai lembaga yang mengatur lalu lintas sektor keuangan di Indonesia telah membagi jenis-jenis inovasi keuangan digital atau yang sering dikenal dengan istilah fintech ke dalam beberapa jenis sesuai dengan kategori manfaat dari fintech tersebut.

Terdapat tiga kategori fintech yang dari masing-masing kategorinya mencangkup macam-macam bentuk inovasi keuangan digital. Tiga kategori tersebut yaitu kategori pembayaran dan transfer, kategori alternatif pengumpulan dana dan pembiayaan dan kategori lainnya. Tiga macam pembagian kategori yang dikeluarkan oleh OJK dapat digambarkan pada tabel berikut :

Tabel 3

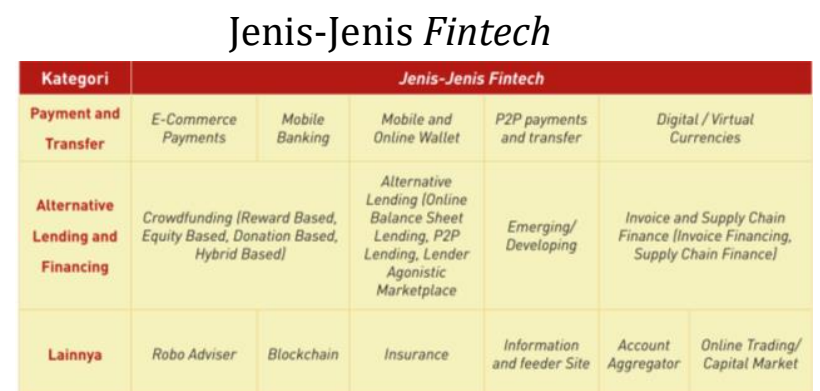

Sumber: Perlindungan Konsumen pada Fintech, OJK (2018:11)

Pada tabel 3 dapat disimpulkan bahwa 0JK telah menetapkan beberapa jenis fintech yang saat ini menjalankan kegiatan usahanya di Indonesia yang termasuk didalamnya sistem crowdfunding. 


\section{Teori Crowdfunding}

Praktik crowdfunding pada dasarnya sudah banyak digunakan oleh masyarakat jauh sebelum istilah crowdfunding digunakan. Menurut Koren (2010) praktik crowdfunding sendiri sebenarnya sudah ada dan telah dipraktikan jauh sebelum masehi, yaitu berupa kontribusi masyarakat dalam pengumpulan dana sumbangan untuk berbagai macam kegiatan amal.

Istilah "crowdfunding" belum memiliki terjemah kata dalam Bahasa Indonesia yang baku. Jika dipelajari dari padanan kata yang digunakan maka crowdfunding memiliki makna "pendanaan oleh khalayak" sedangkan bagi banyak platform crowdfunding di Indonesia mengartikan crowdfunding dengan arti "urun daya". Definisi umum dari crowdfunding dapat disamakan dengan penggalangan dana yang sering dilakukan oleh kelompok masyarakat secara tradisional. Indonesia sudah sejak lama mengenal crowdfunding dengan kata "patungan" atau kata "urunan" sebagai istilah dari pengumpulan dana yang bernominal kecil dari banyak kelompok individu. Wade (2013) mendefinisikan crowdfunding sebagai suatu proses pengumpulan dana atau modal yang biasanya dilakukan melalui media internet, untuk keperluan pendanaan proyek usaha dengan mekanisme pengumpulan uang kecil dari banyaknya peserta donatur dana yang umumnya memiliki minat dan ideologi yang sama.

Penggalangan dana crowdfunding biasanya dapat dilakukan oleh siapapun yang mau menjadi kreator pada platformnya. Sedangkan platform web crowdfunding hanya dijadikan sebagai wadah sekaligus media penghubung yang juga membantu mengkampanyekan proyek. Pada umumnya mekanisme crowdfunding dapat digambarkan sebagai berikut:

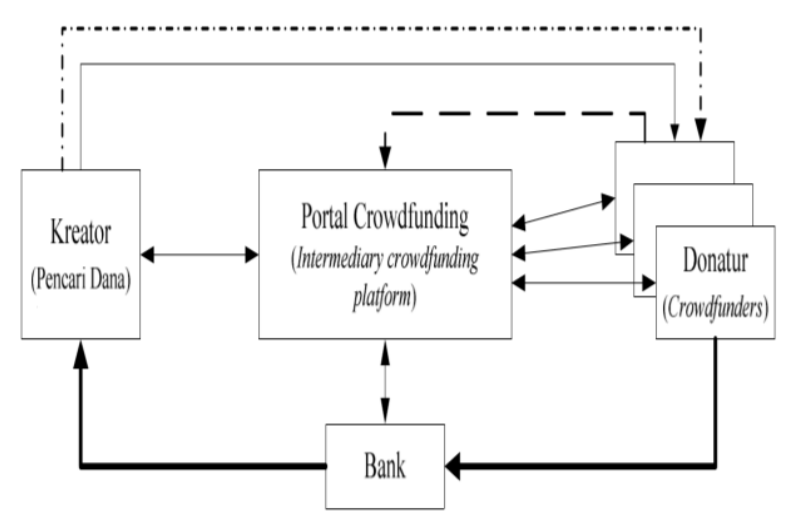

Gambar 1.

Mekanisme Crowdfunding

Pemeran utama yang bertanggungjawab dalam mekanisme crowdfunding adalah kreator atau penggalang dana yang menggagas penggalangan dana, sedangkan portal crowdfunding bergerak sebagai media penghubung (intermediary), dan masyarakat sebagai donatur atau penyandang dana. Pada tahap awal seorang kreator harus melakukan registrasi terlebih dahulu untuk mendaftarkan dirinya dan proyek yang akan digagasnya. Setelah melakukan pendaftaran registrasi, kreator mengajukan proposal yang didalamnya mengandung maksud dan tujuan penggalangan dana untuk pembiayaan suatu proyek kepada platform crowdfunding. Platform crowdfunding bersamaan dengan itu menyeleksi proposal yang dikirimkan dengan menentukan layak atau tidaknya proyek didanai.

Apabila usulan diterima, maka pihak pengelola platform akan memberitahukan 
kepada kreator bahwa proyek penggalangan dana telah berhasil ditampilkan untuk selanjutnya ide penggalangan dana tersebut akan diiklankan dan ditampilkan pada beranda portal web dan selama berjalannya periode penggalangan dana pada halaman platform crowdfunding yang umumnya berjalan antara 30 sampai 90 hari, pihak pengelola platform crowdfunding maupun kreator berusaha melakukan kampanye dan sosialisasi untuk mengiklankan penggalangan dana melalui media sosial maupun secara langsung kepada donatur.

Masyarakat yang tertarik pada proyek penggalangan dana dapat berpartisipasi untuk menjadi donatur dengan cara mengikuti langkah-langkah donasi yang diatur oleh platform. Pengiriman dana dapat dilakukan melalui media transfer antar bank atau uang elektronik ke rekening milik platform crowdfunding. Apabila sampai habis waktu penggalangan dana target terkumpul, maka dana dapat dicairkan oleh kreator dan dana akan ditransfer ke rekening kreator proyek, tetapi bila dana yang dikumpulkan tidak mencapai target, atau terdapat kendala lain selama masa penggalangan dana, maka dana tersebut akan dikembalikan kepada donatur atau dana akan dialihkan kepada proyek lain yang juga sedang ditampilkan pada halaman platform crowdfunding. Hemer (2011:11-12) menegaskan, jika memandang crowdfunding dari latar komersial, ternyata dapat diklasifikasikan menjadi tiga macam, antara lain; not for profit (nirlaba), for profit (usaha) dan intermediate.

\section{Metode Penelitian}

Penelitian ini mengangkat tema tentang faktor-faktor yang dapat mempengaruhi masyarakat berpartisipasi menyalurkan donasi melalui platform crowdfunding berbasis online. Metode penelitian menggunakan Structural Equation Modelling (SEM) karena dianggap mampu menggambarkan keadaan yang sesungguhnya dan sesuai dengan variabel penelitian yang merupakan variabel laten. Analisis SEM akan diolah menggunakan AMOS 22. Selanjutnya hasil dari penelitian ini akan dideskripsikan pada kesimpulan penelitian.

Sampel dalam penelitian ini menggunakan metode non probability sampling dengan purposive sampling, yaitu teknik pengambilan sampel yang tidak memberikan peluang atau kesempatan yang sama bagi anggota populasi untuk dapat menjadi sampel dan memberikan respon penelitian. Pengambilan sempel penelitian menggunakan metode accidental. Singarimbun dan Effendi dalam Soehartami (2006), mengungkapkan maksud accidental adalah konsep pemilihan sampel yang terjadi secara kebetulan terhadap populasi yang ditemui dimasa penelitian. Penentuan jumlah ukuran sampel minimum yang diperlukan sebagai syarat untuk penelitian dengan Structural Equation Modeling (SEM) untuk dapat mengurangi bias pada setiap estimasi SEM adalah 200 (Loehlin, 1998).

Metode pengambilan data yang akan digunakan pada penelitian ini adalah dengan kuesioner dan wawancara. Kuesioner adalah daftar pertanyaan yang mencakup semua pernyataan dan 
pertanyaan yang akan digunakan untuk mendapatkan data, baik yang dilakukan melalui telepon, surat, atau bertatap muka (Ferdinand, 2006). Menurut Rangkuti (1997) tujuan kuesioner adalah memperoleh informasi yang relevan dengan tujuan survei, memperoleh informasi dengan tingkat keandalan dan tingkat keabsahan setinggi mungkin. Dalam penelitian ini, responden diberikan pertanyaan-pertanyaan oleh peneliti dan peneliti sekaligus melakukan supervisi untuk menghindarkan kesalahan persepsi dari responden terhadap pertanyaan. Pelaksanaan kuesioner dilakukan dengan menggunakan metode riset online untuk dapat memudahkan penelitian.

Riset online adalah riset yang dilakukan secara online dengan menggunakan media elektronik yang memanfaatkan email dan web untuk mengumpulkan data dimana responden dapat ditemui dimana saja tidak dibatasi letak geografis saat riset dijalankan (Sarwono, 2012:4). Pertanyaanpertanyaan dalam kuesioner (angket) tertutup dibuat dengan menggunakan skala likert dengan perhitungan skala 1-4 untuk mendapatkan data yang bersifat interval. (Nazir, 1983:397).

Metode wawancara digunakan sebagai teknik pengumpulan data apabila peneliti ingin melakukan studi pendahuluan untuk menemukan permasalahan yang harus diteliti, dan juga apabila peneliti ingin mengetahui hal-hal dari responden yang lebih mendalam dengan jumlah responden sedikit atau kecil (Sugiyono, 2015:137). Jenis dari metode wawancara yang digunakan adalah wawancara tidak terstruktur dimana tidak digunakannya pedoman wawancara yang telah tersusun secara sistematis dan lengkap untuk pengumpulan datanya (Sugiyono, 2015:138). Metode wawancara dilakuan untuk mengklarifikasi temuan-temuan penelitian dengan tujuan memperkuat argumentasi hasil penelitian.

Teknik analisis data digunakan untuk menginterpretasikan dan menganalisis data. Sesuai dengan variabel yang ada dalam penelitian ini maka alat analisis yang digunakan adalah Structural Equation Modeling (SEM) yang dioperasikan melalui program SPSS AMOS 22. Penggunaan metode SEM banyak digunakan untuk model yang kompleks, untuk mengetahui hubungan antar variabel. Menurut Widarjono (2010:309) langkah pengukuran yang dapat dilakukan dalam menganalisis SEM adalah spesifikasi model, identifikasi model, estimasi model, uji kelayakan model dan uji signifikansi dan interpretasi serta respesiifikasi model.

\section{HASIL DAN PEMBAHASAN}

Pengujian dengan Structural Equation Modeling (SEM) pada umumnya didahului dengan analisis konfirmatori faktor (Confirmatory Factor Analysis, CFA). Menurut Wijayanto (2008: 25), CFA didasarkan dengan alasan bahwa variabel-variabel teramati adalah indikator-indikator yang tidak sempurna dari variabel-variabel laten ataupun konstruk tertentu yang mendasarinya.

Analisis konfirmatori digunakan untuk menguji konsep yang dibangun dengan menggunakan beberapa indikator terukur. Setelah data kuesioner berhasil direkapitulasi dan lolos dalam uji validitas dan reliabilitas selanjutnya CFA dapat dilakukan dengan mengolah data 
menggunakan sistem AMOS 22. Sebelum mengetahui hasil analisis konfirmatori faktor terlebih dahulu dilakukan uji kesesuaian model untuk mencapai nilai maximum likelhood. Uji kesesuaian model dapat diketahui dengan menggunakan hasil dari goodness of fit index yang meliputi Chi-Square, probability, RMSEA, GFI, AGFI, CFI, TLI dan CMIN/DF.

Hasil dari analisis konfirmatori faktor dapat dilihat melalui gambar berikut:

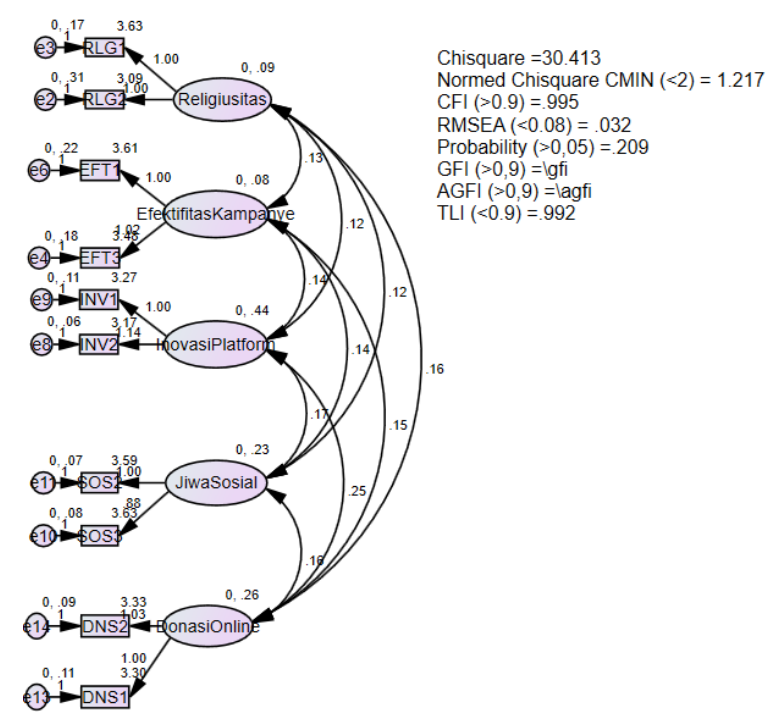

Gambar 2.

Analisis Konfirmatori Faktor

Masing-masing variabel memiliki nilai $t$-value positif dan hal ini menandakan bahwa masing-masing variabel mampu mengkonfirmasi secara positif kepada variabel lainnya.

Hasil analisis konfirmatori tersebut juga dijelaskan dengan persamaanpersamaan berikut :

a) Variabel Religiusitas

$$
\text { RLG1 }=1,00 \text { Religiusitas }+3,63
$$$$
\text { RLG2 = 1,00 Religiusitas }+3,09
$$

Model diatas menunjukkan hubungan antara setiap indikator pembentuk variabel religiusitas, setiap terjadi kenaikan religiusitas sebesar 1 satuan akan diikuti dengan kenaikan RLG1 sebesar 3,63 dan RLG2 sebesar 3,09 , dengan tingkat loading factor seabesar 3,63 menunjukkan bahwa indikator mempunyai peran lebih dominan dibandingkan indikator lain yang membentuk variabel religiusitas.

b) Variabel Efektifitas Kampanye EFT1 $=1,00$ Efektifitas kampanye $+3,61$ EFT3 $=1,00$ Efektifitas kampanye $+3,48$

Model pada gambar 2 menunjukkan hubungan antara setiap indikator pembentuk variabel efektifitas campaign, setiap terjadi kenaikan efektifitas campaign sebesar 1 satuan akan diikuti dengan kenaikan EFT1 sebesar 3,61 dan, EFT3 sebesar 3,48. Indikator EFT1 dengan tingkat loading factor sebesar 3,61 menunjukkan bahwa indikator mempunyai peran lebih dominan dibandingkan indikator lain yang membentuk variabel efektifitas kampanye.

c) Variabel Inovasi Platform

INV1 $=1,00$ Inovasi platform $+3,27$

INV2 $=1,14$ Inovasi platform $+3,17$

Model pada gambar 2 menunjukkan hubungan antara setiap indikator pembentuk variabel inovasi platform, setiap terjadi kenaikan inovasi platform sebesar 1 satuan akan diikuti dengan kenaikan INV1 sebesar 3,27 dan INV2 sebesar 3,17. Indikator INV1 dengan tingkat loading mempunyai peran lebih dominan dibandingkan indikator lain yang membentuk variabel inovasi platform.

d) Variabel Jiwa Sosial

SOS2 $=1,00$ Jiwa sosial $+3,59$

SOS3 $=0,88$ Jiwa sosial $+3,63$

Model gambar 2 menunjukkan hubungan antara setiap indikator pembentuk variabel Jiwa Sosial, setiap 
terjadi kenaikan Jiwa Sosial sebesar 1 satuan akan diikuti dengan kenaikan SOS2 sebesar 3,5 dan SOS3 sebesar 3,63. Indikator SOS3 dengan tingkat loading factor sebesar 3,63 menunjukkan bahwa indikator mempunyai peran lebih dominan dibandingkan indikator lain yang membentuk variabel jiwa sosial.

e) Variabel Donasi Online

DNS1 $=1.00$ donasi online $+3,30$

DNS2 $=1,03$ donasi online $+3,33$

Model pada gambar 2 menunjukkan hubungan antara setiap indikator pembentuk variabel donasi online, setiap terjadi kenaikan donasi online sebesar 1 satuan akan diikuti dengan kenaikan DNS1 sebesar 3.30 dan DNS2 sebesar 3,33 . Indikator DNS1 dengan tingkat loading factor sebesar 3,33 menunjukkan bahwa indikator mempunyai peran lebih dominan yang membentuk variabel donasi online.

Selanjutnya uji goodness of fit index analisis konfirmatori dalam peneitian ini dapat dilihat sebagai berikut :

Tabel 4

Goodnes fo Fit Index CFA

\begin{tabular}{|l|l|l|l|}
\hline $\begin{array}{c}\text { Goodnes of } \\
\text { Fit Index }\end{array}$ & $\begin{array}{c}\text { Cut- } \\
\text { Off } \\
\text { Value }\end{array}$ & $\begin{array}{c}\text { Hasil } \\
\text { Uji } \\
\text { Model }\end{array}$ & Keterangan \\
\hline Chisquare & $1-5$ & 30,413 & Baik \\
\hline Probability & $>0,05$ & 0,209 & Baik \\
\hline CMIN & $<2$ & 1,217 & Baik \\
\hline RMSEA & $<0.08$ & 0,032 & Baik \\
\hline CFI & $>0.95$ & 0,995 & Baik \\
\hline GFI & $>0,90$ & 0,973 & Baik \\
\hline AGFI & $>0,90$ & 0,940 & Baik \\
\hline TLI & $>0,95$ & 0,992 & Baik \\
\hline
\end{tabular}

Sumber: Data diolah, peneliti (2018)

Menurut tabel 4 dapat diketahui hasil chi square sebesar 30,413 dengan probabilitas $0,209 \geq 0,05$, nilai RMSEA sebesar 0,032 $\leq 0,08$, nilai GFI sebesar $0,973 \geq 0,90$, nilai AGFI sebesar $0,940 \geq$ 0,90, nilai CMIN/DF sebesar 1,217 $\leq 2$, nilai TLI sebesar $0,992 \geq 0,95$, dan nilai CFI sebesar 0,995 $\geq 0,95$ yang menunjukkan bahwa uji kesesuaian model dapat diterima dengan baik. Sehingga dapat diambil kesimpulan bahwa indikator-indikator ini dapat diterima. Hal ini membuktikan indikator secara nyata membentuk variabel religiusitas, efektifitas kampanye, inovasi platform, jiwa sosial dan donasi online.

$$
\text { Langkah selanjutnya yaitu }
$$
menentukan analisis model SEM. Analisis ini digunakan untuk mengetahui hubungan struktural antara variabel yang diteliti. Setelah dilakukan analisis konfirmatori faktor dan telah memenuhi standar goodnes of fit index maka analisis penelitian ini layak untuk dilanjutkan untuk diteliti hubungan struktural yang terjadi antara variabel dan dapat dilakukan pengujian kesesuaian dengan goodness of fit index kembali. Hasil analisis SEM dalam penelitian ini dapat digambarkan seperti gambar berikut :

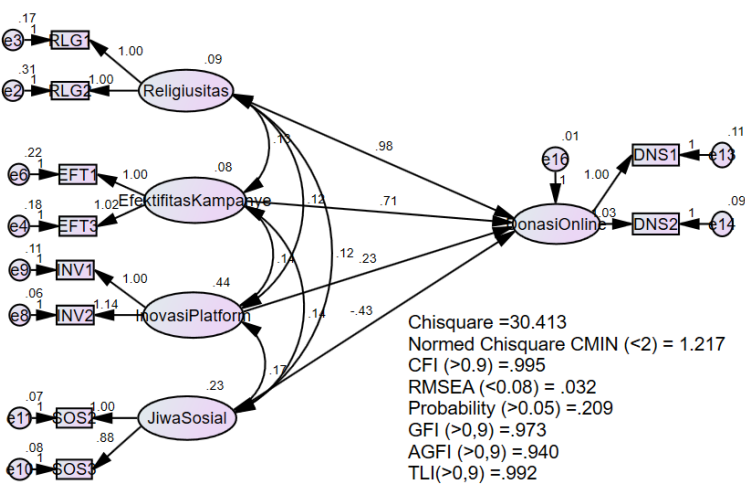

Gambar 3

Uji Model SEM

Dari gambar 3 diatas dapat dilihat secara langsung pada uji model variabel religiusitas memiliki $t$-value sebesar 0,98 , artinya variabel religiusitas berpengaruh positif terhadap variabel donasi online. Selanjutnya variabel efektifitas kampanye memiliki t-value sebesar 0,71 yang 
artinya berpengaruh positif terhadap variabel donasi online. Variabel inovasi platform juga berpengaruh positif terhadap variabel donasi online dengan besaran nilai t-value sebesar 0,23. Sedangkan variabel jiwa sosial memiliki nilai $t$-value negatif sebesar $-0,43$, hal ini menunjukkan bahwa faktor jiwa sosial tidak mempengaruhi keputusan masyarakat dalam menyalurkan donasi melalui crowdfunding berbasis online.

Dari hasil uji model dalam penelitian menggunakan metode SEM dapat diketahui bahwa variabel religiusitas merupakan variabel yang paling berpengaruh dan paling dominan dalam membentuk variabel donasi online. Sedangkan variabel jiwa sosial tidak berpengaruh terhadap variabel donasi online atau lebih jelasnya diperoleh hasil model struktural sebagai berikut :

$\mathrm{Y}$ (Donasi Online) $=\alpha+0,98$ Religiusitas $+0,71 \quad$ Efektifitas Kampanye + 0,23 Inovasi Platform 0,43 Jiwa Sosial + ê

Pada tahapan uji selanjutnya yaitu uji goodnes of fit Index yang berfungsi menguji keabsahan penelitian dan hasilnya telah tertulis di rumus model dan dapat dijabarkan sebagai berikut:

Tabel 5

Godness Of Fit Index Model SEM

\begin{tabular}{|l|l|l|l|}
\hline $\begin{array}{c}\text { Goodnes of } \\
\text { Fit Index }\end{array}$ & $\begin{array}{c}\text { Cut- } \\
\text { Off } \\
\text { Value }\end{array}$ & $\begin{array}{c}\text { Hasil Uji } \\
\text { Model }\end{array}$ & Keterangan \\
\hline Chisquare & $1-5$ & 30,413 & BAIK \\
\hline Probability & $>0,05$ & 0,209 & BAIK \\
\hline CMIN & $<2$ & 1,217 & BAIK \\
\hline RMSEA & $<0.08$ & 0,032 & BAIK \\
\hline CFI & $>0.95$ & 0,995 & BAIK \\
\hline GFI & $>0,90$ & 0,973 & BAIK \\
\hline AGFI & $>0,90$ & 0,940 & BAIK \\
\hline TLI & $>0,95$ & 0,992 & BAIK \\
\hline
\end{tabular}

Sumber: Data diolah, peneliti (2018)
Menurut tabel 5 dapat diketahui hasil chi square sebesar 30,413 dengan perolehan nilai probabilitas 0,209 $\geq 0,05$, perolehan nilai RMSEA sebesar 0,032 $\leq$ 0,08, perolehan nilai GFI sebesar $0,973 \geq$ 0,90 , perolehan nilai AGFI sebesar $0,940 \geq$ 0,90, perolehan nilai CMIN/DF sebesar $1,217 \leq 2$, perolehan nilai TLI sebesar $0,992 \geq 0,95$, dan perolehan nilai CFI sebesar $0,995 \geq 0,95$ yang menunjukkan bahwa uji kesesuaian model dapat diterima dengan baik. Sehingga dapat diambil kesimpulan bahwa indikatorindikator ini dapat diterima. Hal ini membuktikan indikator secara nyata membentuk variabel religiusitas, efektifitas kampanye, inovasi platform, jiwa sosial dan donasi online.

Tahapan selanjutnya adalah pengujian hipotesis untuk mengetahui berpengaruh atau tidaknya variabel independen terhadap variabel dependen. Hipotesis dinyatakan diterima jika nilai probability $(\mathrm{P})<0,05$ atau jika nilai C.R lebih besar dari nilai kritisnya. Nilai $t$ tabel atau nilai kritis yang ditentukan dalam penelitian ini adalah 1,984 dengan jumlah variabel 5 dan sampel 216.

Berdasarkan hasil pengolahan data bahwa tiga indikator pembentuk variabel laten menunjukkan hasil yang memenuhi kriteria yaitu nilai C.R di atas nilai t tabel dengan $(\alpha)$ 0,05 sebesar 1,984 atau dengan nilai $\mathrm{P}$ (probability) lebih kecil dari pada 0,05. Hal ini menandakan bahwa variabel religiusitas, variabel efektifitas kampanye dan variabel inovasi platform berpengaruh positif dan signifikan terhadap masyarakat untuk ikut menyalurkan donasi melalui crowdfunding berbasis online, sedangkan variabel jiwa sosial memiliki pengaruh negatif dan nilai signifikansi probability 
0.08 yang masih bisa ditoleransi dengan keputusan signifikan. Selanjutnya dapat diketahui bahwa variabel religiusitas mempunyai pengaruh terkuat dibandingkan variabel lain dengan C.R sebesar 3,470 terhadap variabel donasi online. sedangkan variabel Jiwa sosial memiliki nilai C.R negatif yaitu $-1,727$ dengan nilai $\mathrm{p} \mathrm{0,08}$ yang masih dalam batas yang bisa ditoleransi yaitu $<0,10$.

Hasil wawancara menunjukkan bahwa donatur ikut berpartisipasi dalam crowdfunding online disebabkan karena banyak hal, yang paling dominan adalah karena media donasi online merupakan tren yang sedang banyak diikuti oleh masyarakat dan strategi iklan pada media sosial telah berhasil menarik minat masyarakat untuk berdonasi secara online. Masyarakat masih memiliki kepercayaan yang tinggi terhadap platform crowdfunding online yang dapat dimanfaatkan sebagai suatu sistem untuk dijadikan alat yang memiliki respon cepat terhadap keadaan masyarakat. Sedangkan hasil dari keseluruhan penelitian menunjukkan bahwa variabel lain yang mempengaruhi masyarakat telah diukur dalam penelitian ini. Dari keempat variabel yang diuji, tiga diantaranya memiliki nilai positif dan satu nilai negatif. Pembahasan dari masing-masing variabel yang diukur dapat digambarkan sebagai berikut:

\section{Pengaruh Religiusitas terhadap Donasi Online}

Berdasarkan hasil statistik, dapat diketahui bahwa tingkat religiusitas masyarakat berpengaruh positif dan signifikan terhadap kepuasan. Hal ini dibuktikan dari hasil nilai P (probability) sebesar < 0,05 dengan nilai estimate 0,984 yang menunjukkan hasil positif, yang berarti jika kualitas nilai religiusitas masyarakat naik maka akan berpengaruh positif terhadap keputusan masyarakat ikut serta menyalurkan donasi melalui crowdfunding berbasis online.

\section{Pengaruh Efektifitas Kampanye terhadap Donasi Online}

Berdasarkan hasil statistik pengolahan data, dapat diketahui bahwa Efektifitas Kampanye dari yang dilakukan baik oleh pihak kreator atau inisiator yang menggagas penggalangan donasi maupun platform berpengaruh positif dan signifikan terhadap keputusan masyarakat menyalurkan donasi melalui crowdfunding berbasis online. Hal ini dibuktikan dari hasil nilai $\mathrm{P}$ (probability) sebesar 0,029<0,05 dengan nilai estimate 0,714 yang menunjukkan hasil positif, yang berarti jika Efektifitas Kampanye naik maka sangat mempengaruhi keputusan masyarakat untuk ikut serta menyalurkan donasi melalui crowdfunding berbasis online.

\section{Pengaruh Inovasi Platform terhadap Donasi Online}

Berdasarkan hasil statistik, dapat diketahui bahwa inovasi yang dilakukan oleh platform penggalangan donasi berbasis online berpengaruh positif dan signifikan terhadap keputusan masyarakat untuk ikut serta menyalurkan donasi berbasis online dengan arahnya sesuai dengan hipotesis dengan nilai probability < 0,05 dan nilai estimasi sebesar 0,226 yang berarti positif.

\section{Pengaruh Jiwa Sosial terhadap Donasi Online}

Berdasarkan hasil statistik, dapat diketahui bahwa tinggi rendahnya jiwa sosial masyarakat berpengaruh negatif dan signifikan terhadap keputusan masyarakat untuk ikut serta menyalurkan 
donasi melalui crowdfunding berbasis online dengan arahnya berlawanan dengan hipotesis. Hal ini berarti jika nilai jiwa sosial seperti rasa empati dan tanggungjawab sosial masyarakat tinggi maka tidak akan meningkatkan keputusan masyarakat untuk ikut serta menyalurkan donasi melalui crowdfunding berbasis online. Hal ini diakibatkan karena menurut masyarakat apabila seseorang memiliki jiwa sosial yang semakin tinggi maka orang tersebut lebih memilih untuk membantu langsung saat merasa empati dan tidak menggunakan donasi dengan sistem online.

Menurut hasil analisis SEM, "Rasa Empati" menjadi indikator yang dianggap responden paling tinggi sebagai indikator yang mempengaruhi masyarakat untuk ikut serta menyalurkan donasi melalui crowdfunding berbasis online. Sedangkan "Gotong royong" menjadi indikator kedua yang dianggap responden mampu mempengaruhi masyarakat untuk ikut serta menyalurkan donasi melalui sistem crowdfunding berbasis online.

\section{KESIMPULAN DAN IMPLIKASI}

\section{Kesimpulan}

Hasil penelitian menunjukkan bahwa variabel religiusitas, efektifitas kampanye dan inovasi platform berpengaruh positif terhadap keputusan masyarakat untuk menyalurkan donasi melalui sistem crowdfunding berbasis online. Sedangkan variabel jiwa sosial memiliki pengaruh negatif dan secara keseluruhan variabel yang diteliti memiliki nilai yang cukup signifikan.

Hal ini bertentangan dengan dugaan awal hipotesis yang menyatakan bahwa faktor religiusitas, efektifitas kampanye, inovasi platform dan jiwa sosial mempengaruhi keputusan masyarakat dalam menyalurkan doasi melalui crowdfunding berbasis online. Kesimpulan negatifnya variabel jiwa sosial diperkuat dengan argumentasi hasil wawancara, dimana temuan menunjukkan bahwa para donatur menyalurkan donasi online bukan didasari oleh tingginya jiwa sosial. Masyarakat berpendapat, apabila seseorang memiliki jiwa sosial yang tinggi maka orang tersebut lebih cenderung untuk membantu atau berdonasi langsung kepada objek donasi tanpa menggunakan sistem online. Masyarakat juga berpendapat bahwa mereka tertarik untuk berdonasi online karena hal tersebut merupakan sebuah tren yang sedang dikenal oleh masyarakat sehingga banyak donatur yang ingin mengikuti tren tersebut.

\section{Implikasi}

Bagi pihak pengelola platform penggalangan donasi online untuk lebih meningkatkan sosialisasi melalui pendekatan agama, lebih efektif dalam mengiklankan proyek dan terus berinovasi untuk mencapai tujuan tingginya perolehan donasi. Adanya temuan faktor jiwa sosial yang memiliki pengaruh negatif bukan berarti penelitian ini tidak merekomendasikan platform crowdfunding untuk mencari donatur yang memiliki jiwa sosial tinggi karena jika dilihat dari nilai signifikansi variabel jiwa sosial masih cukup signifikan dan masih terdapat banyak faktor yang belum diteliti pada penelitian ini. Oleh karena itu, kampanye penggalangan donasi sudah seharusnya tetap mengkampanyekan penggalangan donasi online karena dari hasil wawancara, 
masyarakat masih memiliki kepercayaan yang tinggi terhadap sistem crowdfunding berbasis online.

\section{DAFTAR PUSTAKA}

Andriansyah, Miftah, Teddy Oswari, Budi Prijanto. (2009). Crowdsourcing: Konsep Sumber Daya Kerumunan dalam Abad Partisipasi Komunitas Internet. Jurnal Politeknik Telkom Bandung

Aprilia, Lady. Wibowo S. Sigit . (2017). The impact of social capital on crowdfunding performance. The South East Asian Journal of Management.

Berglin, Henrik, Strandberg, C. (2013). Leveraging Customers As Investors: The Driving Forces Behind Crowdfunding. Tesis tidak dipublikasikan: Uppsala University, Swedia.

Bram, Yudi Farola. 2005 . Analisis Efektivitas Iklan sebagai Salah Satu Strategi Pemasaran Perusahaan Percetakan dan Penerbitan PT. Rambang dengan Menggunakan Metode EPIC Model. Jurnal Manajemen \& Bisnis Sriwijaya Vol 3 No. 6 ( hal 1-23).

Boeuf, Benjamin., Darveau, Jessica., and Legoux, Renaud. Crowdfunding as a New Approach for Theatre Projects. International Journal of Arts Management.

Effendi, Ratna Mufidha. (2008). Hubungan Religiusitas Dengan Perilaku Agresi Remaja Madrasah Tsanawiyah Persiapan Negeri Batu (Skripsi Sarjana). Fakultas Psikologi Universitas Islam Negeri, Malang.
Fauzia, Nurul. (2017). Internet Sebagai Media Fundarising. Skripsi Mahasiswa UIN Sunan Kalijaga. Yogyakarta.

Ferdinand, A. (2006). Metode Penelitian Manajemen : Metode Penelitian Skripsi, Tesis dan Disertasi IImu Manajemen. Semarang: Badan Penerbit Universitas Diponegoro.

Ghozali, I. (2006). Aplikasi Analisis Multivariate dengan Program SPSS, Edisi ke-4. Semarang: Badan Penerbit Universitas Diponegoro.

Gleasure, R., Feller, J. (2016). Emerging technologies and the democratisation of financial services: A metatriangulation of crowdfunding research. Information and Organization.

Gobble, M. A. M. (2012). Everyone is a venture capitalist: the new age of crowdfunding. Research technology management

Hemer, Joachim. (2011). A Snapshot on Crowdfunding. Karlsruhe, Jerman: Working Papers Firms and Region, Fraunhover Institute for System and Innovation Research ISI

Hermawan, A. d. (2013). E-Bussines \& ECommerce. Yogyakarta: Andi.

Indriantoro, N. S. (1999). Metode Penelitian Bisnis untuk Akuntansi dan Manajemen. Yogyakarta: Penerbit BPFE.

Jugiyanto, Hartono. (2011). Metodologi Penelitian Bisnis: Salah Kaprah dan Pengalaman-pengalaman. Yogyakarta: Penerbit BPFE

Koren, G. (2010, October 12). A History of Crowdfunding. Retrieved from Crowdsourcing and Crowdfunding The Industry 
Lambert, T. dan A. Schwienbacher. (2010). An Empirical Analysis of Crowdfunding, diakses dari http://ssrn.com/abstract=1578175. Mustafa dan Usman H (2007). Proses Penelitian Kuantitatif. Jakarta: Lembaga Penerbit Fakultas Ekonomi Universitas Indonesia.

Ordanini, A. (2009), "Crowd funding: customers as investors", The Wall Street Journal.

Ordanini, A., Miceli, L., Pizzetti, M., \& Parasuraman, A. (2011). Crowdfunding: Transforming customers into investors through innovative service platforms. Journal of Service Management.

Parasuraman, A. dan G. M. Zinkhan. (2002). Marketing to and serving customers through the Internet: An overview and research agenda. Journal of The Academy of Marketing Science.

Rahayu, C. C. (2013). Penggalangan Dana Model Crowdfunding di Indonesia. Depok: Universitas Indonesia.

Rangkuti, F. (1997). Analisis SWOT Teknik Membedah Kasus Bisnis. Jakarta: Gramedia Pustaka Utama.

Ratna, N. K. (2011). Teori, Metode, dan Teknik Penelitian Sastra dari Strkturalisme Hingga Postrukturalisme Perspektif Wacana Naratif. Yogyakarta: Pustaka Pelajar.

Ries, Eric. (2011). The Lean Startup: How Today's Entrepreneurs Use Continuous Innovation to Create Radically Successful Businesses. New York, USA: Fletcher \& Company

Ries, Eric. (2013). The Lean Startup. Yogyakarta: Bentang.

Rizky, M.F. \& Yasin, H. (2014). Pengaruh Promosi dna Harga Terhadap Minat
Beli Perumahan Obama PT. Nailah Adi Kurnia Sei Mencirim Medan. Jurnal Manajemen \& Binsis, Vol. 14(2), hal. 135-143.

Santoso, Singgih. (2014). Statistik Multivariat Edisi Revisi. Jakarta: PT Elex Media Komputindo.

Sarwono, Jonathan. (2012). Metode Riset Online: Teori, Praktek dan pembuatan Aplikasi Menggunakan HTML, PHP dan CSS. Jakarta: Elex Media Komputindo

Sitanggang, March Hot Asi. (2017). Memahami

Crowdfunding Dan Motivasi Berpartisipasi Dalam Platform Kitabisa.com. Departemen Ilmu Komunikasi Fakultas Ilmu Sosial dan Ilmu Politik Universitas Diponegoro

Sri, Yunita dkk. (2012). Religiusitas Pada Hijabbers Community Bandung. Prosiding Seminar Nasional Penelitian PKM: Sosial Ekonomi dan Humaniora

Sugiyono., P. D. (2015). Metode Penelitian Kuantitatif Kualitatif dan R\&D Cetakan ke-22 . Bandung: CV Alfa Beta.

Sunarti. (2003). Partisipasi Masyarakat dalam Pembangunan Perumahan secara kelompok. Jurnal Tata Loka.

Suryawan, A. (2004). Studi partisipasi Masyarakat dalam Pelestarian dan Pengembangan Kawasn Alun-alun Surakarta. Skripsi Pendidikan Program Sarjana Jurusan teknik Perencanaan Wilayah dan Kota, 37.

Sunyoto, D., dan Setiawan, A. (2013). Statistika Kesehatan : Paramatrik, Non paramatik, Validitas, dan Reliabilitas. Yogyakarta: Nuha medika. 
Thomas W Zimmerer, Norman M Scarborough.

(2008). Kewirausahaan dan Manajemen Usaha Kecil. Jakarta. Salemba Empat. Tridanatna, Nia Utami. Vina Gerogina dan Yen Sun. (2014). Evaluasi Good Corporate Governance Atas Kebutuhan Donatur Pada Penerapan Crowdfunding Di Indonesia: Studi Kuantitatif Dan Kualitatif Pada Efekrumahkaca.Net, Patungan.Net, Dan Wujudkan.Com. Jurnal ComTech Vol. 5 No. 1 Juni (2014)

Wheat, R.E., Wang, Y., Byrnes, J.E, Ranganathan, J. (2013) 'Raising money for sctientific research through Crowdfunding, Trends in Ecology \& Evolution, Vol. 28, No. 2

Wicks, Mike. (2013). Crowdfunding - An Introductuon. Victoria: Blue Beetle Books.

Widarjono, Agus. (2010). Analisis Statistika Multivariat Terapan. Edisi pertama. Yogyakarta: UPP STIM YKPN
Widiyanto, I. (2008). Pointers: Metodologi Penelitian. Semarang: PB Undip.

Wijayanto. (2008). Structural Equation Modeling dengan Lisrel 8.8 : Konsep \& Tutorial. Jakarta. Graha Ilmu.

Yahya bin Syaraf An-Nawawi, Al Imam Abu Zakaria. (1999). Terjemahan Riyadhus Shalihin. Jakarta: Pustaka Amani.

Yaqin, Mohammad Ainol Tijaniyah. (2017). Sinergitas E-Crowdfunding Dengan E-Commerce Dalam Membantu Pendanaan Sosial Berbasis Web Bootstrap. Prosiding SNATIF ke-4

Young, T. E. 2012. The Everything Guide to Crowdfunding: Learn how to use social media for small-business funding. Adams Media 